\title{
Actualization of Charging Direct Current Electric Fan with Solar Energy
}

\author{
${ }^{1}$ Olawuni A., ${ }^{1}$ Omotayo M. E., ${ }^{1}$ Olaoye O. T. and ${ }^{4}$ Ola B. O. \\ ${ }^{I}$ Department of Electrical/Electronic Engineering, Osun State Polytechnic, Iree, Nigeria \\ ${ }^{2}$ Department of Computer Engineering, Osun State Polytechnic. Iree, Nigeria
}

\begin{abstract}
Sun is an abundant source of energy and it is inexhaustible. Solar radiation is a renewable source of energy, which has become increasingly popular in modern times. This paper, therefore, focused on charging of an electric dc fan using a photovoltaic cell or solar panel. A $100 \mathrm{~W}, 16 \mathrm{~V}$ Mono crystalline Photovoltaic cell $(P V)$ was used to convert the solar radiation to direct current $(d c)$ and it was connected to a charge controller that regulates the charge voltage of the battery. As the temperature increases from $27^{\circ} \mathrm{C}$ to $39^{\circ} \mathrm{C}$, the voltage of the lead-acid battery increases from $11.2 \mathrm{~V}$ to $13.1 \mathrm{~V}$. When the maximum voltage is reached $(13.6 \mathrm{~V})$ the charge controller cut off the charging voltage supplied to the battery. Therefore the dc power supplied to the fan is obtainable from the solar charged $12 \mathrm{~V}$ battery.
\end{abstract}

Keywords: Sun, Photovoltaic cell, Charge controller, Battery

\section{Introduction}

Solar radiation is a renewable source of energy, which has become increasingly popular in modern times. It has obvious advantages over non-renewable energy sources, such as coal, oil and nuclear energy. It is non-polluting, reliable and can produce energy anywhere that there is sun shining, so its resources are not going to run out anytime soon. It even has advantages over other renewable energy sources, including wind and water power (Zubair et al., 2011).

Sun is an abundant source of energy and it is inexhaustible. In the broadest sense, solar energy supports all life on earth and is the basis for almost every form of energy we use. The sun makes plants grow, which are burned as fuel or rot in swamps and are compressed underground for millions of years to become coal and oil (Roth et al., 2005). Heat from the sun causes temperature differences between areas, causing the wind to blow. Water evaporates because of the sun, water vapours are carried to high elevations, and when the water vapours condense and precipitate as rainfall. The water rushes down towards the sea through rivers, spin turbines is too made for generating electricity. It thus becomes clear that hydroelectricity is an indirect form of solar energy (Abdallah and Nijmeh, 2004). However, direct solar energy can be used as heat, light, and electricity through the use of solar cells.

Solar energy can be converted directly into electrical energy (direct current, dc) by photovoltaic (PV) cells commonly called solar cells. Photovoltaic cells are made of silicon and other materials. When sunlight strikes the silicon atoms it causes electrons to eject (Prasad et al., 2010). A typical solar cell is a transparent wafer that contains a very thin semi conductor as shown in Fig. 1. Sunlight energizes and causes electrons in the semiconductor to flow, creating an electrical current. Solar cells can provide electricity to remote villages.

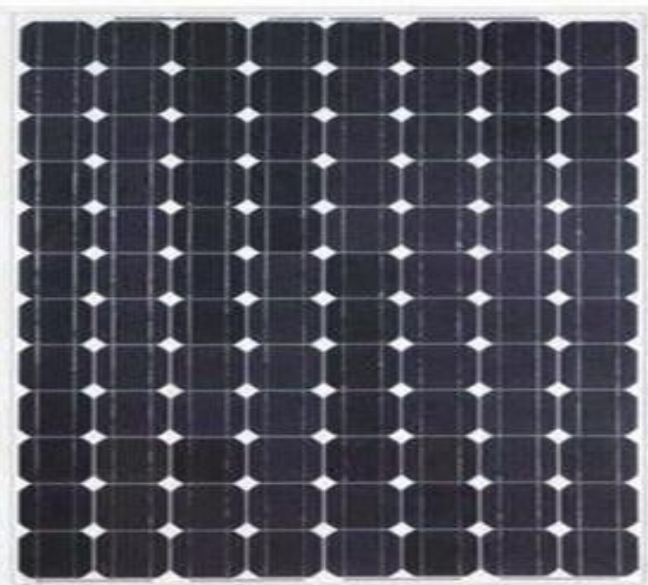

Fig. 1 Picture of a Mono crystalline solar panel

Source: Roth et al. (2005). 
Solar power is generated using solar panels, which do not require any major mechanical parts, such as wind turbines. These mechanical parts can break down and cause maintenance issues and can also be quite noisy. Both of these issues are virtually non-existent with solar panels. Also, the solar cells, that connected together make up the solar panel, can last up to several decades without replacement (Roth et al., 2005).

The increasing population and change in our life style make great demand for energy resources. This ever increasing demand puts great pressure on non-renewable energy sources and makes it necessary that we should look for other alternative energy resources (Sharman \& Hongwei, 2006). The sources like sun and wind can never be exhausted and are thus known as renewable sources of energy; they cause no emission of poisonous gases and are available locally. They are widely available and potential source of clean and limitless sources of energy. Therefore, apart from solar street light, solar energy can be used directly for cooking and charging some direct current (dc) appliances such as mobile phone and electric dc fan. This paper, therefore, focused on the actualization of charging of an electric dc fan using a photovoltaic cell or solar panel.

\section{Materials And Method}

A $100 \mathrm{~W}, 16 \mathrm{~V}$ Mono crystalline Photovoltaic cell (PV) was used as a source of electrical energy to generate a direct current (dc) which was used to charge the lead-acid battery voltage of $12 \mathrm{~V}$. The PV was mounted on the roof of the building in order to catch the incident rays from the sun.

The PV was connected to a charge controller that needs to access the PV and the battery voltage to verify the proper connection and values. The connection is as shown in Fig. 2.0.

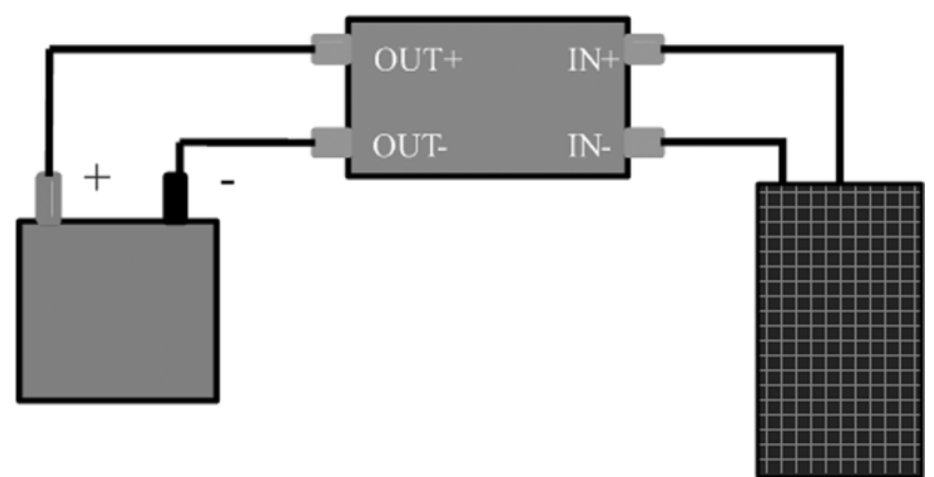

Fig. 2.0 Connection of PV and Battery to Microcontroller

\section{Procedure}

The voltage value of the battery was verified initially by measuring it with a voltmeter before connecting it to charge controller. Texas Instrument, (2013) prescribed that voltage of the battery should be greater than $10 \mathrm{~V}$ but less than $12 \mathrm{~V}$ when it is in good condition. Then, the battery was connected to the output terminals of the microcontroller. The solar panel or solar array simulator was connected to the input of the microcontroller. Also, the battery was loaded by connecting it to a dc electric fan during the night without the solar panel connected to it so as to discharge or return it back to its initial voltage. The dc electric fan was used throughout the night in order to bring the voltage of the battery back to its initial voltage value. This was done every day before being connected to the solar panel and the initial voltage was measured by the voltmeter.

Then the battery charging current was verified with the aid of an ammeter. This was done at different temperature of the day.

The microcontroller has a power supply circuit that would provide a $10 \mathrm{~V}$ power supply rail required to properly bias the SM72485 (microprocessor) gate driver (Reza et al., 2010, Mohan \& Robbins, 1995) as shown in Fig. 2.1

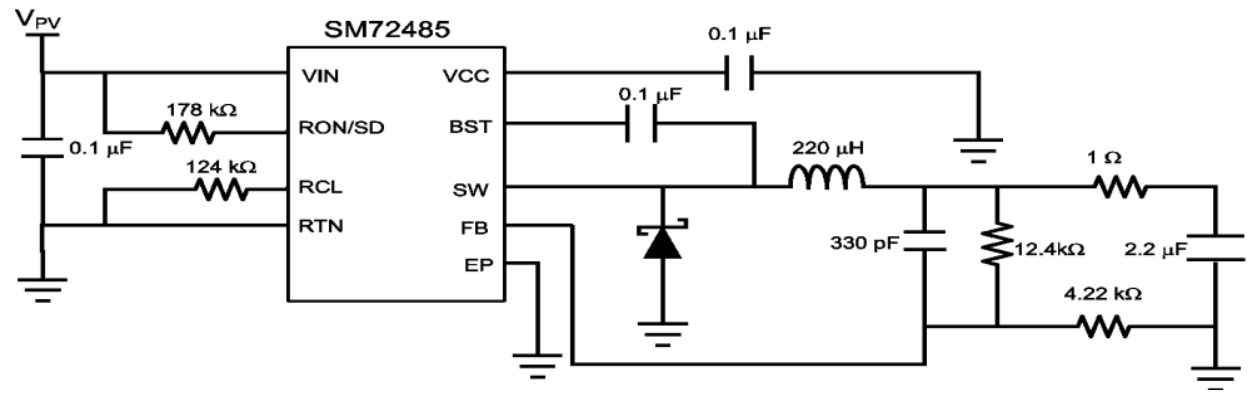

Fig. 2.1 Power Supply Circuit 
Also, microcontroller has a dc/dc converter that step up or step down four switch converter as shown in Fig. 2.2 (Peng et al., 2003, Mitchell, 1988; Kislovski \& Sokal, 1994). This stage transfers the power from the PV panel to the dc electric fan (load). A mechanical fan is a machine used to create flow within a fluid, typically a gas such as air. The fan consists of a rotating arrangement of vanes or blades which act on the air. The rotating assembly of blades and hub is known as an impeller, a rotor, or a runner.

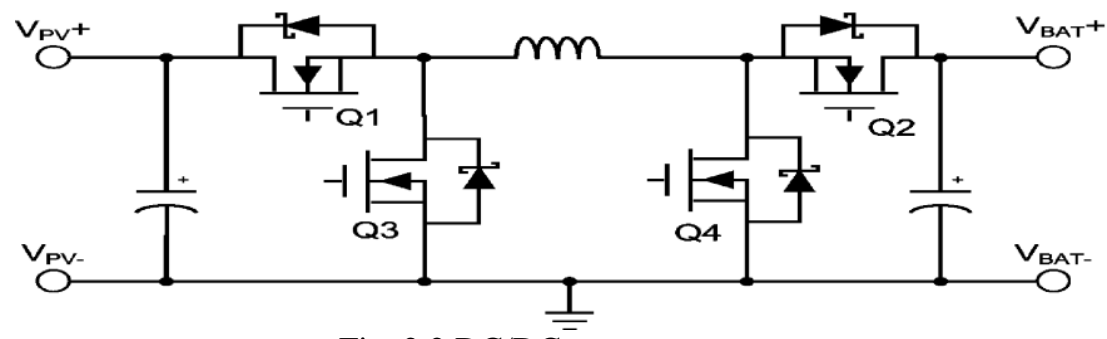

Fig. 2.2 DC/DC converter stage

This fan is either alternating current (ac) type i.e powered by alternating current or direct current (dc) type powered through dc battery. The alternating current type of fan (ac fan) did not make use of battery. The block diagram involved in charging an electric dc fan is as shown in Fig. 2.3.

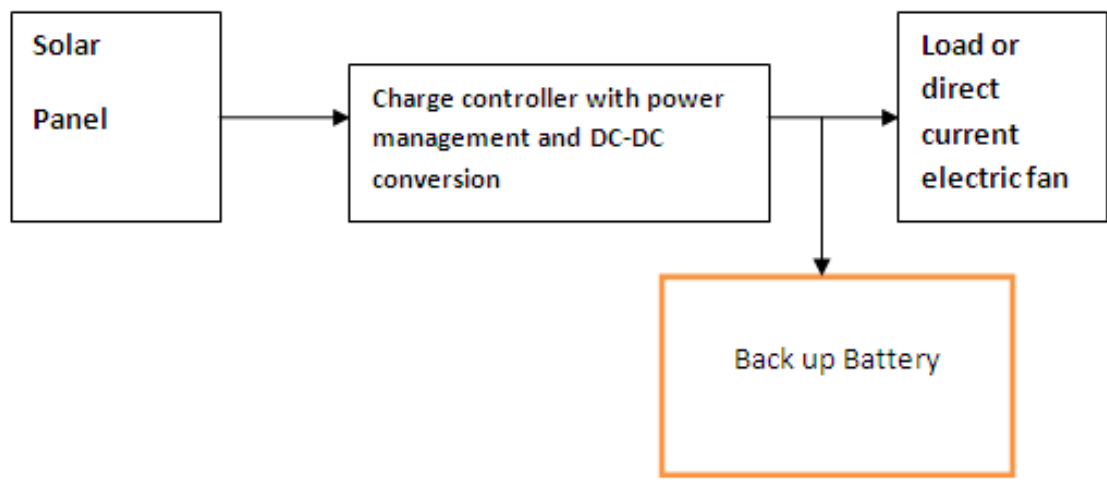

Fig. 2.3 Block Diagram of Direct Current Electric Fan Charged by Solar Panel

\section{Results And Discussion}

The initial voltage of the battery $\left(\mathrm{V}_{\mathrm{o}}\right)$ was $11.2 \mathrm{~V}$ which was measured by a voltmeter. This shows that the battery is in good condition as it was prescribed by Texas Instrument that voltage of the battery should be greater than $10 \mathrm{~V}$ but less than $12 \mathrm{~V}$ when it is in good condition (Texas Instrument, 2013).

The solar panel attracted the rays of the sun during the day and the following results were obtained at different temperature of the day.

Table 3.0 shows the readings obtained by voltmeter used to measure the voltage of the battery at different temperature ranges between $25^{\circ} \mathrm{C}$ and $39^{\circ} \mathrm{C}$. This measurement was taken in five days $\left(\mathrm{D}_{1}\right.$ to $\left.\mathrm{D}_{5}\right)$ and in which the measurement was replicated five times at the same temperature of the same day. It was observed that as temperature increases the voltage of the battery increases. This shows that the dc voltage generated due to the radiation of heat from the sun attracted by the solar panel is charging the battery. The charging current was also measured with the aid of a clamp ammeter. It was observed that the charging current is $0.52 \mathrm{~A}$ which is adequate for the charging of the $12 \mathrm{~V}$ batteries.

The intensity of solar radiation depends on the nature and condition of the weather of the day. Solar radiation produced more power during the brighter sunshine day than cloud cover or when the temperature was low as shown in the table 3.0. In an agreement with Davis instruments, (2010) during cloudy conditions or when the temperature was low, output voltage dropped from about 20 to $30 \%$ of the voltage generated. Time of year also affected the output of the solar radiation: solar intensity is reduced in rainy season. The charging hour of the solar panel is insignificant since direct current generated depends on the intensity of the radiation of the sun. Finally, dust or other materials covering the panel reduced or cut off power output.

The charge controller helped in regulating the amount of voltage used to charge the battery. As the battery is charging from $11.2 \mathrm{~V}$ to $12 \mathrm{~V}$, the charge controller allowed the voltage to flow into the battery. But as the battery reaches its peak or maximum value it stops the flow of voltage into the battery for charging so as not to overcharge or damage the battery. 
Table 3.0: Voltage of the battery at different temperature

\begin{tabular}{|c|c|c|c|c|c|c|}
\hline $\begin{array}{l}\text { Radiation of the } \\
\text { sun }\end{array}$ & $\begin{array}{l}\text { Voltage at } \\
25^{\circ} \mathrm{C} \\
\end{array}$ & Voltage at $28^{\circ} \mathrm{C}$ & $\begin{array}{l}\text { Voltage at } \\
30^{\circ} \mathrm{C}\end{array}$ & $\begin{array}{l}\text { Voltage at } 33^{\circ} \\
\mathrm{C}\end{array}$ & $\begin{array}{l}\text { Voltage at } \\
37^{\circ} \mathrm{C}\end{array}$ & $\begin{array}{l}\text { Voltage at } \\
39^{\circ} \mathrm{C}\end{array}$ \\
\hline $\mathrm{D}_{1}$ & 11.20 & 11.60 & 11.92 & 12.10 & 12.30 & 12.30 \\
\hline $\mathrm{D}_{1}$ & 11.20 & 11.58 & 11.90 & 12.24 & 12.26 & 12.29 \\
\hline $\mathrm{D}_{1}$ & 11.20 & 11.62 & 11.94 & 12.22 & 12.31 & 12.31 \\
\hline $\mathrm{D}_{1}$ & 11.20 & 11.61 & 11.92 & 12.12 & 12.32 & 12.32 \\
\hline $\mathrm{D}_{1}$ & 11.20 & 11.60 & 11.93 & 12.10 & 12.30 & 12.30 \\
\hline $\mathrm{D}_{2}$ & 11.25 & 11.62 & 11.95 & 12.26 & 12.32 & 12.32 \\
\hline $\mathrm{D}_{2}$ & 11.25 & 11.60 & 11.94 & 12.24 & 12.28 & 12.30 \\
\hline $\mathrm{D}_{2}$ & 11.25 & 11.61 & 11.94 & 12.25 & 12.30 & 12.31 \\
\hline $\mathrm{D}_{2}$ & 11.25 & 11.60 & 11.94 & 12.24 & 12.29 & 12.30 \\
\hline $\mathrm{D}_{2}$ & 11.25 & 11.62 & 11.95 & 12.25 & 12.30 & 12.30 \\
\hline $\mathrm{D}_{3}$ & 11.22 & 11.58 & 11.94 & 12.12 & 12.26 & 12.28 \\
\hline $\mathrm{D}_{3}$ & 11.22 & 11.62 & 11.94 & 12.22 & 12.31 & 12.31 \\
\hline $\mathrm{D}_{3}$ & 11.22 & 11.61 & 11.92 & 12.12 & 12.32 & 12.32 \\
\hline $\mathrm{D}_{3}$ & 11.22 & 11.60 & 11.93 & 12.10 & 12.30 & 12.30 \\
\hline $\mathrm{D}_{3}$ & 11.22 & 11.62 & 11.95 & 12.26 & 12.32 & 12.32 \\
\hline $\mathrm{D}_{4}$ & 11.24 & 11.60 & 11.93 & 12.10 & 12.30 & 12.30 \\
\hline $\mathrm{D}_{4}$ & 11.24 & 11.62 & 11.95 & 12.26 & 12.32 & 12.32 \\
\hline $\mathrm{D}_{4}$ & 11.24 & 11.60 & 11.94 & 12.24 & 12.28 & 12.30 \\
\hline $\mathrm{D}_{4}$ & 11.24 & 11.61 & 11.94 & 12.25 & 12.30 & 12.31 \\
\hline $\mathrm{D}_{4}$ & 11.24 & 11.60 & 11.94 & 12.24 & 12.29 & 12.30 \\
\hline $\mathrm{D}_{5}$ & 11.26 & 11.64 & 11.96 & 12.25 & 12.33 & 12.33 \\
\hline $\mathrm{D}_{5}$ & 11.26 & 11.62 & 11.95 & 12.26 & 12.32 & 12.32 \\
\hline $\mathrm{D}_{5}$ & 11.26 & 11.63 & 11.96 & 12.24 & 12.31 & 12.32 \\
\hline $\mathrm{D}_{5}$ & 11.26 & 11.61 & 11.98 & 12.25 & 12.30 & 12.31 \\
\hline $\mathrm{D}_{5}$ & 11.26 & 11.62 & 11.97 & 12.24 & 12.29 & 12.30 \\
\hline
\end{tabular}

Table 3.1 shows the average voltage of the battery at different temperature between $25^{\circ} \mathrm{C}$ and $39^{\circ} \mathrm{C}$ that ranges between $11.200 \mathrm{~V}$ and $12.316 \mathrm{~V}$ respectively.

Table 3.1 Average voltage of the battery

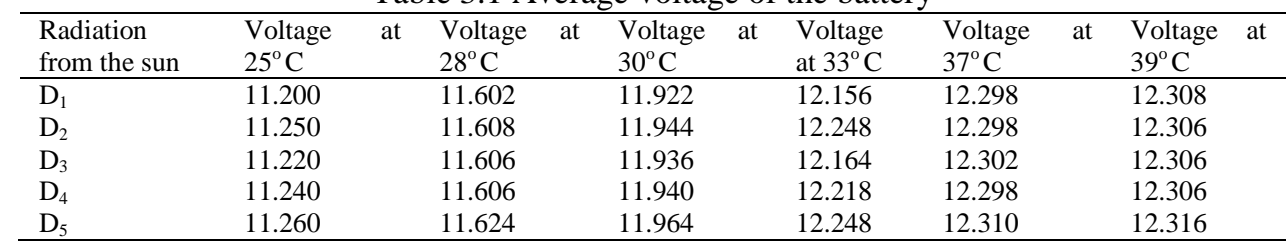

Figure 3.0 shows the graphical representation of the values of the voltage of the battery measured at $25^{\circ}$ $\mathrm{C}$ and $39^{\circ} \mathrm{C}$. This further showed that as temperature increases the voltage of the battery increases. Therefore, the changes in the temperature have effect on the charging of the battery.

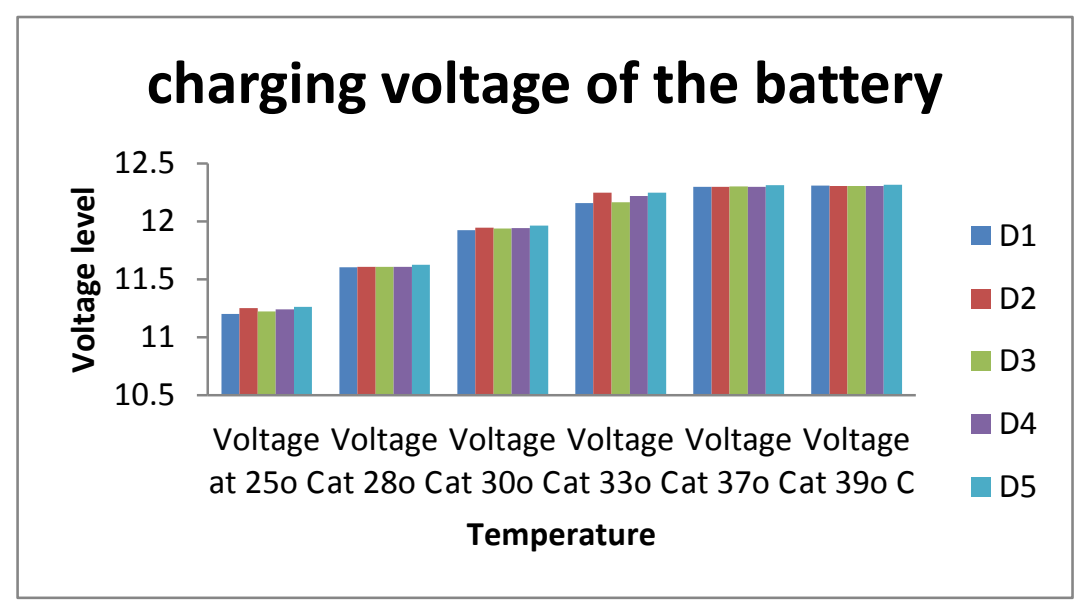

\section{Conclusion}

The sun is often regarded as the ultimate answer to our energy problems. Sun provides a continuous supply of energy that far exceeds our current energy demand. It is free of cost, available in plenty, found everywhere and has no political barrier. The Photovoltaic cell (PV) or solar panel attracts the radiation from the sun and converts it to electrical energy which is used to charge the dc battery in order to power the dc fan. The 
unavailability of electrical power from our electricity generating company has nothing to do with the solar energy which is always available. Also, overcharging of dc battery which can damage the battery is being controlled by the charge controller. Therefore the dc power supplied to the fan is obtainable from the solar charged $12 \mathrm{~V}$ battery.

\section{References}

[1]. Abdallah S. and Nijmeh S., (2004). Two axes sun tracking system with PLC control. Energy

[2]. Convers Manage; 45:1931-9.

[3]. Davis Instruments Corp., (2010). Estimating Power from a Solar Panel, Hayward, USA.

[4]. Kislovski, R. R. and Sokal N., (1994). Dynamic Analysis of Switching-Mode DC/DC Converters, New York: Van Nostrand Reinhold.

[5]. Mitchell D. M., (1988). Dc-Dc Switching Regulator Analysis, New York: McGraw-Hill.

[6]. Mohan N., Undeland T. and Robbins W., (1995). Power Electronics: Converters, Applications, and Design, 2nd ed., New York: John Wiley \& Sons.

[7]. Peng F. Z., Zhang F. and Qian Z., (2003). A novel compact DC-DC converter for 42 V system, in Proc. IEEE Power Electron. Spec. Conf., 33-38.

[8]. Prasad P. R., Byregowda H.V. and Gangavati P. B., (2010). Experiment Analysis of Flat Plate Collector and Comparison of Performance with Tracking Collector, European Journal of Scientific Research. 40 (1):144 -155.

[9]. Reza S. M. K., Shah A. T. and Reza S. M., (2010). Microcontroller Based Automated Water Level Sensing and Controlling: Design and Implementation Issue Proceedings of the World Congress on Engineering and Computer Science Vol I WCECS 2010, October 20-22, 2010, San Francisco, USA

[10]. Roth P, Georgiev A. and Boudinov H., (2005). Cheap two axis sun following device. Energy Convers Manage;46:1179-92.

[11]. Sharma R. and Hongwei G., (2006). Low cost high efficiency Dc-Dc converter for fuel cell powered auxiliary power unit of a heavy vehicle, IEEE Trans. Power Electron., 21(3): 587-591.

[12]. Texas Instrument, (2013). AN-2121 Solar Magic ${ }^{\text {TM }}$ SM3320-BATT-EV Charge Controller Reference Design, Application Report SNOSB76C-May 2013

[13]. Zubair S., Suleiman A., Abdulazzez H. T. and Salihu B. A., (2011). Design and Construction of a Microcontroller Based Single axis Solar Tracker, Innovations in Science and Engineering 1: 41- 47 